smoke but, as there are no data directly relating cotinine levels to risk of death, it is not possible to predict the likely effect of a reduction of this magnitude on the risk of sudden infant death. Our results also suggest that harm reduction measures short of a total ban on smoking in the home are likely to have little effect on the exposure of infants to tobacco smoke, but this requires verification with a larger sample.

We thank the parents who participated; the health visitors, their managers, and staff in the child health departments of the NHS trusts who helped us to recruit our sample; and the nurses who collected the data.

Contributors: See bmj.com

Funding: NS, CB, CC, and RM were supported by the Foundation for the Study of Infant Deaths (grant No 266).

Competing interests: None declared.

Ethical approval: This study was approved by the Coventry and south Birmingham research ethics committees.
Cook DG, Strachan DP. Health effects of passive smoking: summary of effects of parental smoking on the respiratory health of children and effects of parental smoking on the respiratory
implications for research. Thorax 1999:54:357-66.

2 Jarvis M, Goddard E, Higgins V, Feyerabend C, Bryant A. Children's exposure to passive smoking in England since the 1980s: cotinine evidence from population surveys. BMJ 2000;321:343-5.

3 Mascola MA, Van Vunakis H, Tager IB, et al. Exposure of young infants to environmental tobacco smoke: breast-feeding among smoking mothers Am J Public Health 1998;88:893-6.

Graham $\mathrm{H}$. When life's a drag: women, smoking and disadvantage. London: HMSO, 1993.

5 Wakefield M, Banham D, Martin J, Ruffin R, McCaul K, Badcock N. Restrictions on smoking at home and urinary cotinine levels among chilRestrictions on smoking at home and urinary cotin

6 Bakoula C, Kafritsa Y, Kavadias G, et al. Factors modifying exposure to environmental tobacco smoke in children. Cancer Causes Contro 1997;8:73-6.

7 Winklestein M, Tarzian A, Wood R. Parental smoking behaviour and passive smoke exposure in children with asthma. Ann Allergy Asthma Immuno 1997;78:419-23.

8 Haufroid V, Lison D. Urinary cotinine as a tobacco-smoke exposure index: a mini review. Int Arch Occup Environ Health 1998;71:162-8.

9 Peterson EL, Johnson CC, Ownby DR. Use of urinary cotinine and questionnaires in the evaluation of infant exposure to tobacco smoke in epidemiologic studies. J Clin Epidemiol 1997;8:917-23.

(Accepted 9 May 2003)

\title{
Retrospective review of care and outcomes in young adults with type 1 diabetes
}

\author{
C J Wills, A Scott, P G F Swift, M J Davies, A D R Mackie, P Mansell
}

Queen's Medical Centre, Nottingham NG7 2UH

C J Wills specialist registrar

P Mansell

consultant

diabetologist

Derbyshire Royal Infirmary, Derby

DE1 2QY

A Scott

consultant

diabetologist

Leicester Royal

Infirmary, Leicester

LE1 5WW

P G F Swift

consultant

paediatrician

M J Davies

consultant

diabetologist

Northern General

Hospital, Sheffield

S5 7AU

A D R Mackie

consultant

diabetologist

Correspondence to:

C J Wills

catherinewills1@

hotmail.com

BMJ 2003;327:260-1
The national service framework for diabetes includes standards to improve care and outcomes for young people. ${ }^{1}$ Good glycaemic control delays the onset and progression of microvascular complications, but control can be difficult to achieve, particularly in young people. $^{2}$

\section{Participants, methods, and results}

We did this study in four of the important centres for the care of people with diabetes-Derbyshire Royal Infirmary; University Hospital, Nottingham; Northern General Hospital, Sheffield; and Leicester Royal Infirmary. Each centre has a dedicated clinic for young people.

We searched for people aged 16 to 25 who were being followed up for type 1 diabetes. We collected data retrospectively from case notes and computer records on glycaemic control, completeness of screening for and prevalence of complications of diabetes, hypertension, and clinic attendance.

Of the 397 patients included, mean $\mathrm{HbA}_{1 \mathrm{c}}$ concentration was $9.5 \%$ (SD 2.0\%). (The assay was standardised to that used in the diabetes control and complications trial $^{2}$; the upper limit of the reference range for people without diabetes is about 6\%.) Glycaemic control was similar in 31 patients who had not had a recent measurement of $\mathrm{HbA}_{1 \mathrm{c}}$ concentration-their mean fructosamine concentration was $404.9 \quad(93.9) \quad \mu \mathrm{mol} / 1$ (reference range $230-280 \mu \mathrm{mol} / \mathrm{l}$ ).

Screening rates and the prevalence of complications varied between centres (table). The low prevalence of retinopathy in centre 2 was confirmed by an independent review of case notes.

Thirty four patients ( $15 \%$ of those tested) were hypertensive (systolic blood pressure was at least 140 $\mathrm{mm} \mathrm{Hg}$ or diastolic blood pressure was at least $85 \mathrm{~mm}$ $\mathrm{Hg})$. Of these, 24 (71\%) had been tested for excretion of protein by the kidneys. Ten $(42 \%)$ had proteinuria or microalbuminuria and eight of these were taking angiotensin converting enzyme inhibitors.

\section{Comment}

For young adults with type 1 diabetes in this study, glycaemic control is generally poor, attendance at the clinic and screening for complications are suboptimal, and microvascular complications are common. Achieving good glycaemic control in youth yields future health, quality of life, and cost benefits but is difficult for many psychological and social reasons. Cooperation between paediatricians and diabetologists should provide a smooth transition of care from childhood to adulthood; many centres have clinics for young adults. Previous studies of young adults in the United kingdom found poor glycaemic control. ${ }^{3}$ In our study, control was comparable to that of conventionally treated adolescents in the diabetes control and complications trial. ${ }^{2}$

Some European cohorts have lower mean concentrations of glycated haemoglobin, ${ }^{4}$ perhaps due to structured programmes teaching self management. The dose adjustment for normal eating (DAFNE) programme, based on a programme used in Germany, was a success in the United Kingdom and is being evaluated on a wider scale.

Each $1 \%$ fall in $\mathrm{HbA}_{\mathrm{cc}}$ concentration leads to an estimated fall of $30 \%$ in the risk of microvascular complications. ${ }^{2}$ Patients in our centres are at more risk than patients in centres with lower mean $\mathrm{HbA}_{1 c}$ concentrations. Also, the prevalence of complications in our study concerns us. Screening for complications is sub- 
Care and outcomes of 16-25 year olds with type 1 diabetes in four centres in Trent, United Kingdom

\begin{tabular}{|c|c|c|c|c|c|}
\hline \multirow[b]{2}{*}{ Characteristic } & \multicolumn{4}{|c|}{ Centre } & \multirow[b]{2}{*}{ Total } \\
\hline & 1 & 2 & 3 & 4 & \\
\hline All patients & 92 & 115 & 119 & 71 & 397 \\
\hline Mean (SD) age (years) & $22.0(2.1)$ & $19.9(2.6)$ & $20.7(2.4)$ & $18.3(1.7)$ & $20.3(2.6)$ \\
\hline Mean (SD) duration of diabetes (years) & $11.6(5.6)$ & $8.7(5.4)$ & $11.0(6.1)$ & $8.9(4.4)$ & $10.0(5.6)$ \\
\hline Clinic non-attendance ${ }^{\star}$ & - & 24.4 & 18.2 & 31.2 & - \\
\hline Mean (SD) $\mathrm{HbA}_{1 \mathrm{c}}(\%)$ & $9.4(1.6)$ & $9.1(2.1)$ & $9.5(2.1)$ & $9.8(2.1)$ & $9.4(2.0)$ \\
\hline No of patients with diabetes for 7 years or more & 69 & 66 & 86 & 45 & 266 \\
\hline \multicolumn{6}{|l|}{ Patients with diabetes for 7 years or more } \\
\hline Mean (SD) duration of diabetes (years) & $13.8(4.7)$ & $12.2(3.9)$ & $13.6(4.4)$ & $11.4(3.3)$ & $13.0(4.3)$ \\
\hline Mean (SD) $\mathrm{HbA}_{1 \mathrm{c}}(\%)$ & $9.3(1.5)$ & $9.3(1.9)$ & $9.5(2.0)$ & $9.7(2.0)$ & $9.5(1.9)$ \\
\hline $\begin{array}{l}\text { No (\%) of patients tested for hypertension within } 18 \text { months } \\
\text { of audit }\end{array}$ & $68 / 69(99)$ & $52 / 66(79)$ & $75 / 86(87)$ & $40 / 45(89)$ & $235 / 266(88)$ \\
\hline No (\%) of patients with hypertension† & 9/68 (13) & $10 / 52(19)$ & $10 / 75(13)$ & $5 / 40(13)$ & $34 / 235$ (15) \\
\hline No (\%) of patients screened for nephropathy & $60 / 69(87)$ & $30 / 66(45)$ & $29 / 86(34)$ & $31 / 45(69)$ & $150 / 266(56)$ \\
\hline $\begin{array}{l}\text { No }(\%) \text { of patients with positive result in test for } \\
\text { nephropathy } \ddagger\end{array}$ & $17 / 60(28 \%)$ & $4 / 30(13)$ & $7 / 29(24)$ & $4 / 31(13)$ & $32 / 150(21)$ \\
\hline $\begin{array}{l}\text { No (\%) of patients with background retinopathy at latest } \\
\text { screening }\end{array}$ & $18 / 60(30)$ & $2 / 54(4)$ & $14 / 86(16)$ & $12 / 38(31)$ & $46 / 238(19)$ \\
\hline $\begin{array}{l}\text { No }(\%) \text { of patients with preproliferative, proliferative, or } \\
\text { laser treated retinopathy at latest retinal screening }\end{array}$ & $12 / 60(20)$ & $2 / 54(4)$ & $3 / 86(3)$ & $5 / 38(13)$ & $22 / 238(9)$ \\
\hline
\end{tabular}

${ }^{*}$ Ratio of appointments not attended to the total number of appointments offered over the previous 5 years, or since diagnosis if less than 5 years, expressed as a percentage. †Systolic blood pressure at least $140 \mathrm{~mm} \mathrm{Hg}$ or diastolic blood pressure at least $85 \mathrm{~mm} \mathrm{Hg}$.

$\ddagger$ Dipstick proteinuria or a urinary albumin to creatinine ratio $>2.5 \mathrm{mg} / \mathrm{mmol}$. One test is not diagnostic but identifies patients who should be followed closely.

optimal, partly because of poor attendance rates. Young adults may have difficulty complying with traditional clinic systems, and non-attenders are at greatest risk of complications. The attendance rate was highest in the centre that offered appointments in the evening and reminded patients by letter or telephone. All centres in this study had limited resources, with inadequate access to dietetic and psychological services in particular.

We are failing to achieve high standards of care for young adults with diabetes-a problem which is likely to affect the entire United Kingdom. To improve standards of care, we need to evaluate and share outcomes of practice, examine reasons for poor outcomes, and learn from (European) centres that achieve better results.

We thank K Price, Northern General Hospital, Sheffield, and D Kitchener, Leicester Royal Infirmary, for help with data collection.
Contributors: CJW, AS, MJD, and ADRM collected data. CJW constructed the joint database. All authors prepared the manuscript. AS and PM designed the study. CJW is guarantor.

Funding: No additional funding.

Competing interests: None declared.

1 Department of Health. National service framework for diabetes: standards. London: Department of Health, 2001.

2 The diabetes control and complications trial research group. The effect of intensive treatment of diabetes on the development and progression of long-term complications in insulin-dependent diabetes mellitus. $\mathrm{N} \mathrm{Engl} \mathrm{J}$ Med 1993;329:977-86.

3 Bryden KS, Peveler RC, Stein A, Neil A, Mayou RA, Dunger DB. Psychological course of diabetes from adolescence to young adulthood. Diabetes Care 2001;24:1536-40.

4 Dorchy $\mathrm{H}$. What level of HbAlc can be achieved in young diabetic patients beyond the honeymoon period? Diabetes Care 1993;16: 1311-3.

5 DAFNE Study Group. Training in flexible, intensive insulin management to enable dietary freedom in people with type 1 diabetes: dose adjustment for normal eating (DAFNE) randomised controlled trial. BMJ 2002;325:746-9

(Accepted 23 May 2003)

\section{British biological warfare}

In 1763 Sir Jeffrey Amhurst, commander in chief of the British forces fighting a North American Indian uprising west of the Allegheny mountains, wrote to Colonel Bouquet: "Could it not be contrived to send the Smallpox among those disaffected tribes of Indians?"

Bouquet replied: "I shall try and inoculate them with some blankets, and take care not to get the disease myself. As it is a pity to expose good men against them, I wish we could use the Spanish method, to hunt them with English dogs who would, I think, effectively extirpate or remove that vermin."

Amhurst answered: "You will do well to try to inoculate the Indians by means of blankets as well as to try every other method that can serve to extirpate this exorable race."

Captain Simeon Ecuyer, commandant of Fort Pitt, noted in his journal on 24 June: "Out of regard for them [two Indian chiefs] we gave them two blankets and a handkerchief out of the Smallpox hospital. I hope it will have the required effect."
However, in 1803 President Jefferson encouraged the Indians to be vaccinated so "that they would not only be secured by it from the smallpox but that it would finally extirpate that disease from the earth."

Jeremy Hugh Baron homorary professorial lecturer, Mount Sinai School of Medicine, New York, USA

Further reading

Parkman F. The conspiracy of Pontiac. Vol 2. Boston: Little Brown, 1910:44.

Stearn EW, Stearn AE. The effect of smallpox on the destiny of the Amerindian. Boston: B Humphries, 1945:44-45, 56-57. Sipe CH. The Indian wars of Pennsyluania. 2nd ed. Lewisberg, PA: Wennawoods, 1995:423-4. 